\title{
Distribution of abundant prokaryotic organisms in the water column of the central Baltic Sea with an oxic-anoxic interface
}

\author{
Matthias Labrenz*, Günter Jost, Klaus Jürgens \\ IOW (Institut für Ostseeforschung Warnemünde)-Baltic Sea Research Institute Warnemünde, \\ Department of Biological Oceanography, Seestrasse 1, 18119 Rostock-Warnemünde, Germany
}

\begin{abstract}
Anoxic marine deeps are characterized by their chemically stratified water columns. This has implications for the vertical distribution of microbial assemblages, but knowledge of this distribution is still poor. To further evaluate these systems we investigated the Fårö Deep (central Baltic Sea), which was anoxic in its bottom waters in August 2003. To resolve the vertical distribution of the dominating prokaryotic microorganisms along the physico-chemical gradients, we used $16 \mathrm{~S}$ rRNA or 16S rRNA gene-based single strand conformation polymorphism (SSCP) and denaturing gradient gel electrophoresis (DGGE). Altogether, 43 microorganisms were differentiated by sequencing of gel bands; $55 \%$ of these belonged to Phylum Proteobacteria, $24 \%$ to Phylum Bacteroidetes, $7 \%$ to Class Actinobacteria, $5 \%$ to Phylum Cyanobacteria, $2 \%$ were distantly related to the genus Nitrospina and 5\% were identified as Phylum Crenarchaeota. Only $10 \%$ of the investigated assemblages were identified by both fingerprinting methods used. However, both methods revealed dominant 16S rRNA bands, the sequences of which were related to the following organisms: a phototrophic Synechococcus in the photic zone, an aerobic and heterotrophic Pseudoalteromonas in the oxic to suboxic zone, and an anaerobic and autotrophic nitrate-reducing Epsilonproteobacterium in the anoxic to sulphidic zone. The latter 2 bacterial taxa have also been reported from other anoxic basins and seem to be characteristic of marine pelagic redoxclines, indicating that these environments could harbor similar microbial communities.
\end{abstract}

KEY WORDS: Central Baltic Sea · Pelagic prokaryotes · Synechococcus · Pseudoalteromonas · Epsilonproteobacteria

\section{INTRODUCTION}

The Baltic Sea is among the largest brackish basins in the world. The Baltic Proper comprises a number of deep areas with predominantly anoxic conditions in bottom waters. A stable halocline below 60 to $80 \mathrm{~m}$ divides the water column into the upper oxygenated layer and the underlying oxygen-deficient and anoxic/sulphidic layer. The redox gradient around the oxic-anoxic interface is referred to as the pelagic redoxcline, with the chemocline as the zone of first sulfide appearance. Geochemical changes in these water columns are mirrored by different modes of bacterial physiology, from oxic respiration to denitrification, manganese and iron reduction, sulfate reduction, and methanogenesis (Teske et al. 1996). For the central Baltic Sea, a rather large and comprehensive data set of chemical, hydrographical, and microbiological parameters is already available (Rheinheimer et al. 1989, Höfle \& Brettar 1995); however, much less is known about the microbial community structure.

In earlier attempts, this structure was predominantly investigated using cultivation-dependent methods (Bölter \& Rheinheimer 1987, Höfle \& Brettar 1996, Brettar et al. 2001). However, it is well known that cultivation methods rarely reflect the bacterial diversity 
in situ, consequently demanding the use of molecularbased approaches. With regard to the Gotland Basin, these molecular studies were mostly focused on bacteria with special physiological capacities, e.g. new ammonium-oxidizing Nitrospira spp. (Bauer 2003) or anaerobic autotrophic nitrate-reducing bacteria (Brettar et al. 2006). Studies concerning the general molecular microbial diversity in the water column of the central Baltic Sea are rare. Höfle \& Brettar (1995) used a 5S rRNA approach to reveal the microbial diversity of the Gotland Basin, and observed a rather limited number of taxa ( 3 to 7 per layer) throughout the water column; however, due to the low phylogenetic resolution of this technique, a more detailed identification of microbial taxa was not possible.

The general microbial diversity of comparable habitats with oxic-anoxic interfaces has been investigated in a limited number of studies. A stratified marine water column of the Mariager Fjord (Denmark) was investigated in parallel by molecular and culture-dependent approaches, which indicated specific bacterial populations in different layers of the water column (Teske et al. 1996). Delta-subdivision sulphate-reducing bacteria were at maximum cell densities in the anaerobic and anoxic water layers within and below the redoxclines, but the general microbial diversity was not investigated in more detail. A detailed molecular study of the water column in the Black Sea was conducted by Vetriani et al. (2003), in which both clonal libraries and direct fingerprinting by terminal restriction fragment length polymorphism (T-RFLP) analyses were used to assess the archaeal and bacterial communities. An Epsilonproteobacteria- and Pseudoalteromonas-like clone accounted for major peaks in the fingerprint, while deeply branching lineages of Alpha- and Gammaproteobacteria were associated with smaller peaks. However, most recombinant clones were not restricted to a specific depth in the water column, and many of the major T-RFLP peaks remained uncharacterized. Microbial assemblages from the anoxic zone of the Cariaco Basin were investigated using 16S ribosomal DNA libraries (Madrid et al. 2001). Analogous to the Black Sea study (Vetriani et al. 2003), many sequences in the libraries belonged to the Epsilonproteobacteria. Recent CARDFISH analyses even revealed that Epsilonproteobacteria concentrations at these redoxclines could reach up to $30 \%$ of the total bacterial cell counts (Lin et al. 2006).

Taken together, some data concerning the general microbial diversity of permanent anoxic basins like the Black Sea and Cariaco Trench already exist. Thus, with special emphasis on the pelagic redoxcline, our aim was to describe the microbial diversity of potentially abundant microorganisms of the central Baltic Sea, which is characterized by periodically anoxic conditions in its bottom waters.

\section{MATERIALS AND METHODS}

Sampling. Sampling was performed on board the RV 'Alexander von Humboldt' during cruise 44/03/08 conducted in the eastern Gotland Basin (Fårö Deep; Baltic Sea Monitoring Stn 286 [BY 20A], 58 $0.00^{\prime} \mathrm{N}_{\text {; }}$ $19^{\circ} 54.00^{\prime}$ E) (Fig. 1) in August 2003. Water samples were collected from 24 different depths (2 to $180 \mathrm{~m}$ ) by 51 free-flow bottles (Hydrobios) attached to a PVCcoated stainless steel CTD-rosette, and were filtered immediately onto Nuclepore filters (pore size $0.2 \mu \mathrm{m}$ ) and stored frozen at $-80^{\circ} \mathrm{C}$ for later analysis.

Physico-chemical structure of the water column. Chemical profiles of oxygen, hydrogen sulfide, and ammonia, phosphate, nitrite and nitrate were determined as described elsewhere (Grasshoff et al. 1983).

Cell numbers. Bacteria: Flow cytometric analyses were performed after approximately 5 mo of storage according to Gasol et al. (2004). Briefly, subsamples were preserved on board with paraformaldehyde

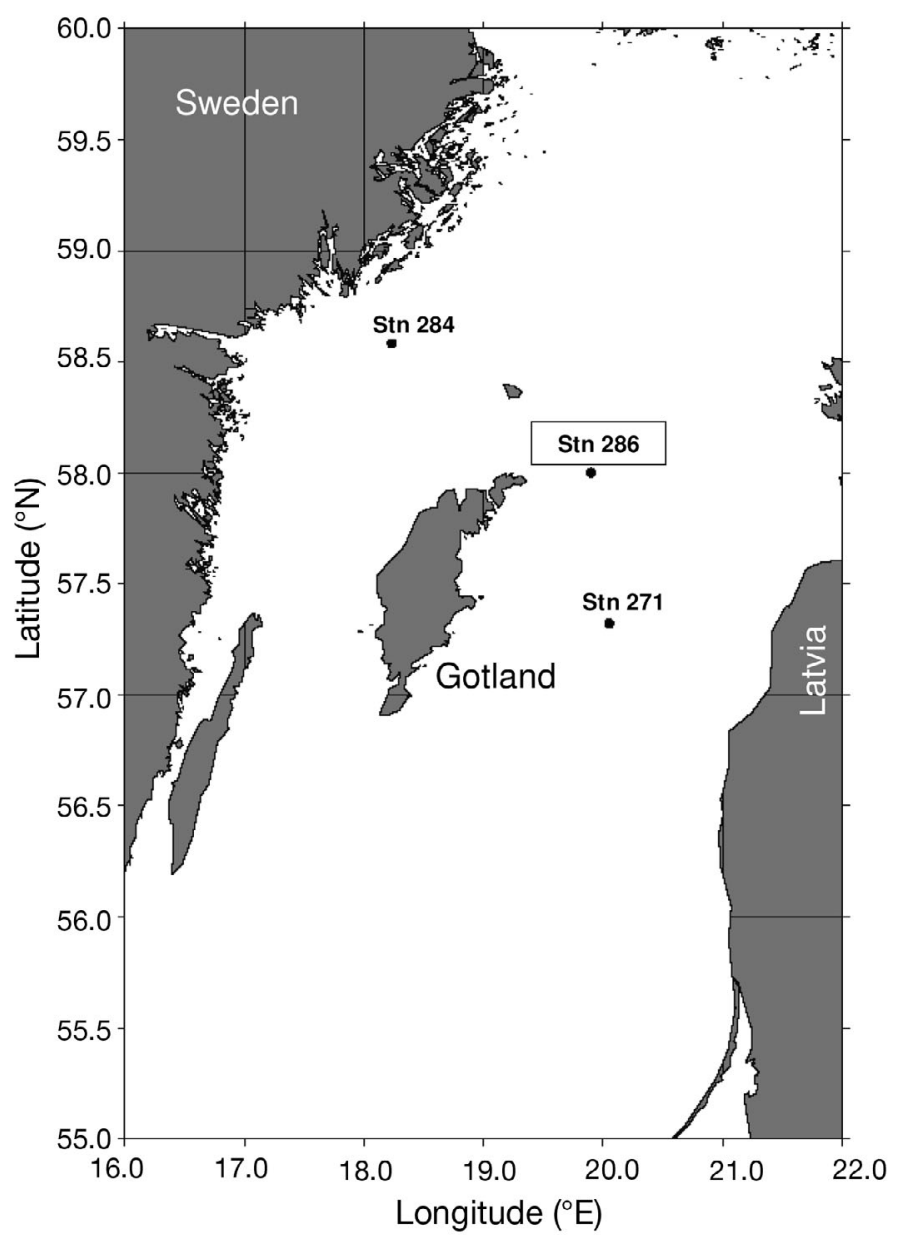

Fig. 1. Central Baltic Sea and location of Stns 286 (our sampling station, Fårö Deep; Baltic Sea Monitoring 286 [BY 20A]), 271 (Gotland Deep) and 284 (Landsort Deep) 
(PFA)/glutardialdehyde (GDA) (1/0.05\% final concentration ratio), frozen in liquid nitrogen and stored in a $-20^{\circ} \mathrm{C}$ freezer on board. In the laboratory, samples were stored at $-80^{\circ} \mathrm{C}$. For analysis, samples were thawed, diluted $10 \times$ to $20 \times$ with Milli-Q water and stained for 15 min with Syto13 $(2.5 \mu \mathrm{M}$ final concentration, Molecular Probes) and processed in a Becton \& Dickinson FACScalibur equipped with a laser emitting at $488 \mathrm{~nm}$. Samples were run at low speed (approx. $15 \mu \mathrm{l} \mathrm{min}{ }^{-1}$ ) until around 10000 events had been recorded. Yellow-green $0.92 \mu \mathrm{m}$ latex beads (Polysciences) were used as an internal standard. Bacteria were detected by their signature in a plot of side scatter (SSC) versus green fluorescence (FL1).

Picocyanobacteria: Picocyanobacteria were analyzed by flow cytometry without staining, at medium

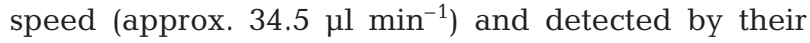
signature in a plot of orange (FL2) versus red fluorescence (FL3).

Nucleic acid extraction and ribosomal complementary DNA (rcDNA) synthesis. Nucleic acid extraction and quantification from the frozen filters was performed by parallel extraction of RNA and DNA using a phenol extraction protocol described by Weinbauer et al. (2002). Prior to RT-PCR, RNA extracts were purified from DNA by incubation with DNase I (DNA-free-Kit, Ambion) for $30 \mathrm{~min}$ at $37^{\circ} \mathrm{C}$ and their concentrations were determined using a NanoDrop ND-1000 spectrophotometer (NanoDrop Technologies). To retrieve 16S rcDNA, 20 ng of template RNA were reverse transcribed at $42^{\circ} \mathrm{C}$ using the iScript cDNA synthesis kit (Bio-Rad). In addition to hexamers provided in the kit, the universal reverse primer 1492R (5'-GGTTACCTTGTTACGACTT-3') (Lane 1991) was also applied. In each reverse transcription reaction, some RNA samples used as controls in the PCR were not supplemented with reverse transcriptase, in order to rule out DNA contamination.

Fingerprint analysis. Our approach was focused on potentially active bacteria. Thus, $16 \mathrm{~S}$ rRNA was predominantly analyzed by DGGE as well as by single strand conformation polymorphism (SSCP). However, in order to obtain an understanding of the structure of abundant microbial communities, 16S rRNA gene profiles throughout the water column were additionally investigated by SSCP.

SSCP: Bacterial Com-primers (amplifying positions 519 to 926 of $E$. coli numbering of 16S rRNA gene) (Schwieger \& Tebbe 1998) were used for 16S rcDNA and 16S rRNA gene amplification. Thermocycling started with an initial denaturation for $5 \mathrm{~min}$ at $94^{\circ} \mathrm{C}$. A total of 25 cycles $\left(30 \mathrm{~s}\right.$ at $94^{\circ} \mathrm{C}, 30 \mathrm{~s}$ at $55^{\circ} \mathrm{C}, 2 \mathrm{~min}$ at $72^{\circ} \mathrm{C}$ ) were followed by a final elongation step of $10 \mathrm{~min}$ at $72^{\circ} \mathrm{C}$. $16 \mathrm{~S}$ rRNA genes were amplified analogously with a total of 35 cycles. Generation and purification of single-stranded DNA (ssDNA) and SSCP analysis were performed according to Schwieger \& Tebbe (1998). Re-amplification of individual bands excised from the SSCP gels was performed as described by Pöhler et al. (2002). PCR products were purified using the MiniElute Kit (Qiagen) as described by the manufacturer, and were sequenced by SEQLAB. Forward and reverse sequences of all samples were checked for accuracy using the SeqMan software (DNASTAR).

DGGE: Two ng of 16S rcDNA was used as template for the PCR. PCR mixtures $(50 \mu \mathrm{l})$ contained bacterial primers 341F-GC and 907R (Muyzer et al. 1995) (each $0.3 \mu \mathrm{M}$ ), each deoxynucleoside triphosphate at $200 \mu \mathrm{M}, 1.25 \mathrm{U}$ of Taq DNA polymerase, and the PCR buffer supplied with the enzyme. Thermocycling started with an initial denaturation step of $94^{\circ} \mathrm{C}$ for $5 \mathrm{~min}$, followed by 10 touchdown cycles of denaturation at $94^{\circ} \mathrm{C}$ for $1 \mathrm{~min}$, annealing at $65^{\circ} \mathrm{C}$ (decreasing in each cycle by $1^{\circ} \mathrm{C}$ ) for $1 \mathrm{~min}$, and extension at $72^{\circ} \mathrm{C}$ for $3 \mathrm{~min}$. This was followed by another 20 cycles at $94^{\circ} \mathrm{C}$ for $1 \mathrm{~min}, 55^{\circ} \mathrm{C}$ for $1 \mathrm{~min}$ and $72^{\circ} \mathrm{C}$ for $3 \mathrm{~min}$. During the last cycle, the extension step was increased to 5 min. Electrophoresis was performed with $6 \%$ polyacrylamide gels (ratio of acrylamide to bisacrylamide: 37.5/1) submerged in $1 \times$ TAE buffer $(40 \mathrm{mM}$ Tris, $40 \mathrm{mM}$ acetic acid, $1 \mathrm{M}$ EDTA; $\mathrm{pH} \mathrm{7.4)}$ at $60^{\circ} \mathrm{C}$. Around $30 \mu \mathrm{l}$ of PCR product were loaded into each lane. Electrophoresis conditions were $100 \mathrm{~V}$ for $16 \mathrm{~h}$ in a linear denaturing gradient of 40 to $80 \%$ (100\% denaturant agent was defined as $7 \mathrm{M}$ urea and $40 \%$ deionised formamide). The gels were stained for $30 \mathrm{~min}$ in $1 \times$ TAE buffer with ethidium bromide and were visualised by UV radiation; images were taken using a digital gel documentation system (Syngene, Gene Snap).

Relative quantification of gel bands. Digitized images of SSCP and DGGE gels were processed with Quantity One ${ }^{\circledR}$ 1-D Analysis software (Bio-Rad). The software carries out a density profile through each lane, detects the bands and then calculates the relative contribution of each band to the total band signal in the lane after applying a rolling disk as background subtraction. Bands occupying the same position in different lanes were identified.

Phylogenetic analyses. Phylogenetic affiliations of the partial 16S rRNA sequences were initially estimated using the basic local alignment search tool (BLAST; Altschul et al. 1997). Sequences were aligned and analyzed employing the ARB software package (Ludwig et al. 2004). Sequences with similarity greater than $98 \%$ were grouped for phylogenetic analyses. Basic trees were reconstructed based on related public sequences of approximately 1400 nucleotides. These were reduced to unambiguously alignable positions using group-specific $50 \%$ conservation filters. An evolutionary distance dendrogram was constructed using 
the Jukes-Cantor correction and neighbor joining. Bootstrap analyses were performed for basic neighbor joining trees with 1000 resamplings. Finally, partial SSCP or DGGE sequences were individually imported using ARB parsimony and group-specific filters.

Nucleotide sequence accession numbers. The $16 \mathrm{~S}$ rRNA gene sequences determined in this study were deposited in the GenBank database under accession numbers DQ385014 to DQ385056 (see Fig. 9).

\section{RESULTS}

\section{Physico-chemical structure}

The physical as well as chemical parameters of Stn 286 are shown in Fig. 2. Warm surface water (photic zone, mixed layer) from 0 to $20 \mathrm{~m}$ depth was separated from the water beneath by a thermocline (Fig. 2A). A zone of so called 'winter water' with temperatures around $4^{\circ} \mathrm{C}$ remained beneath the thermocline and above the halocline at $75 \mathrm{~m}$ depth. Phosphorus was not detectable within the photic zone, but increased steadily below this zone reaching its maximum and final concentration of about $5 \mu \mathrm{mol} \mathrm{l}^{-1}$ just below the redoxcline. Below the halocline, oxygen decreased sharply to concentrations below $100 \mu \mathrm{mol} \mathrm{l}^{-1}$, reaching values of less than $20 \mu \mathrm{mol} \mathrm{l}^{-1}$ at depths around $90 \mathrm{~m}$ (Fig. 2B). Below this depth, oxygen decreased further and was no longer detectable at $106 \mathrm{~m}$. The pelagic redoxcline was established from approximately 90 to $115 \mathrm{~m}$, with the chemocline at approximately $109 \mathrm{~m}$ depth (Fig. 2). Nitrate decreased sharply from 102 to $110 \mathrm{~m}$ (Fig. 2B). Nitrite was present in small amounts of maximally $0.16 \mu \mathrm{mol} \mathrm{\textrm {l } ^ { - 1 }}$. Ammonium increased strongly below $104 \mathrm{~m}$.
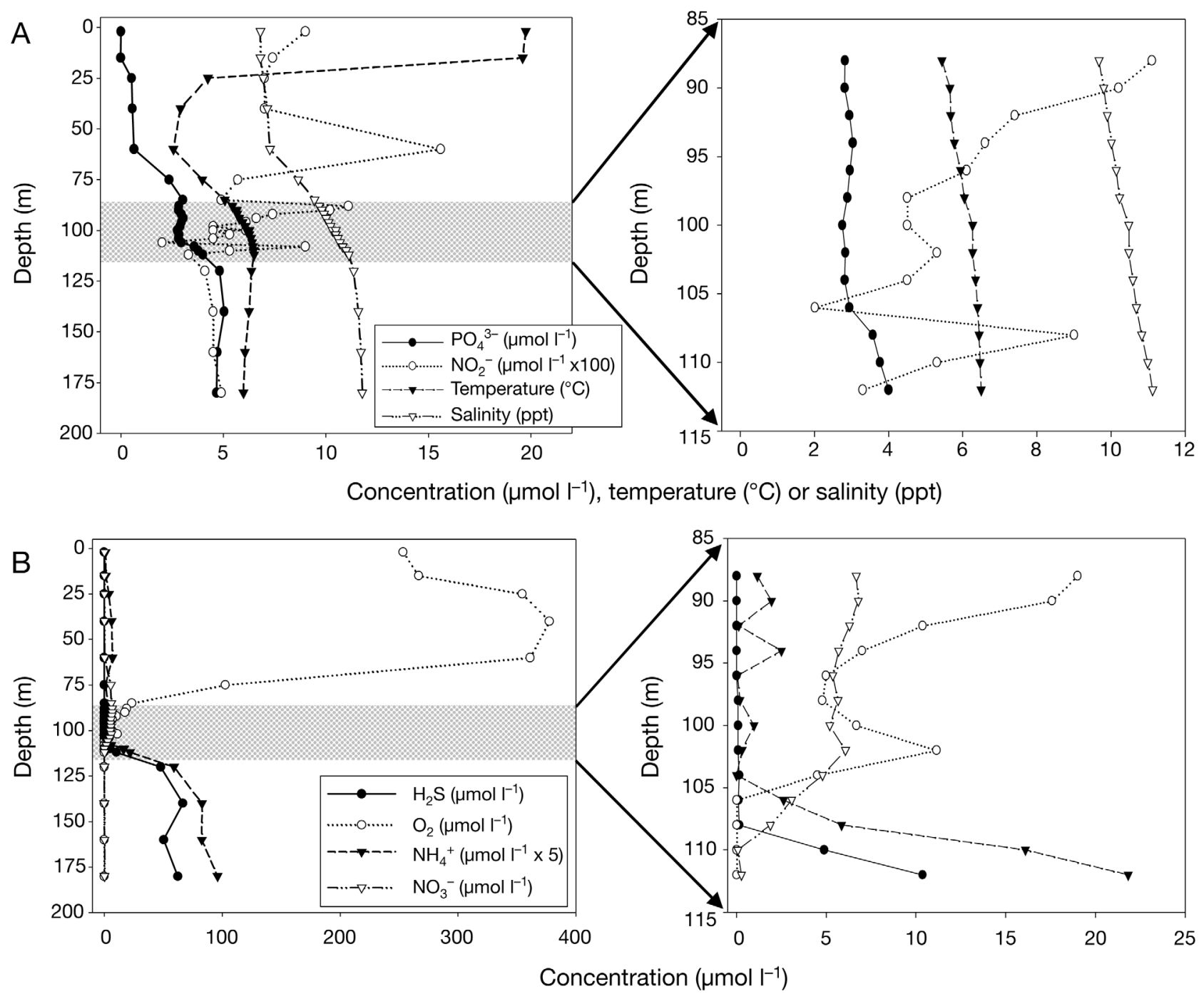

Fig. 2. Depth profiles throughout the water column of Fårö Deep (Stn 286) in August 2003: (A) $\mathrm{PO}_{4}{ }^{3-}$, $\mathrm{NO}_{2}{ }^{-}$, temperature and salinity; (B) $\mathrm{H}_{2} \mathrm{~S}_{2} \mathrm{O}_{2}, \mathrm{NH}_{4}{ }^{+}$and $\mathrm{NO}_{3}{ }^{-}$. Shaded areas denote the redoxcline, shown in detail on the right 


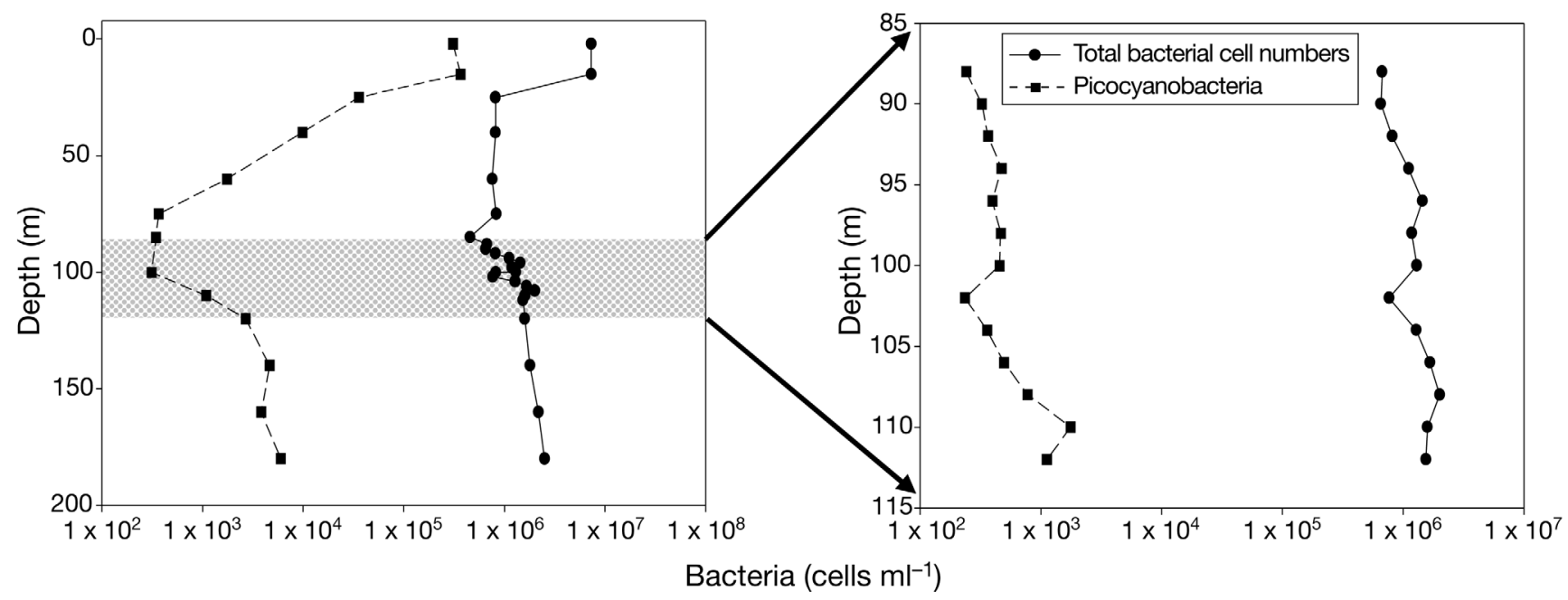

Fig. 3. Bacteria and picocyanobacteria cell numbers throughout the water column (left) and redoxcline (right) of Fårö Deep Stn 286 in August 2003

\section{Cell numbers}

Total bacterial cell numbers were highest in the photic zone (about $7.3 \times 10^{6}$ cells $\mathrm{ml}^{-1}$ ) (Fig. 3). Total cell numbers decreased below the thermocline to around $1 \times 10^{6}$ cells $\mathrm{ml}^{-1}$ and increased again at the redoxcline, reaching $2.5 \times 10^{6}$ cells $\mathrm{ml}^{-1}$. Picocyanobacteria represented 4 to $5 \%$ of the total bacterial cell numbers (about $3.5 \times 10^{5}$ cells ml ${ }^{-1}$ ) in the photic zone. Cell numbers of picocyanobacteria declined continuously below the photic zone, but increased again at the lower end of the redoxcline up to $6.0 \times 10^{3}$ cells $\mathrm{ml}^{-1}$.

\section{Phylogenetic characterization of microorganisms}

Forty-three microorganisms could be differentiated by partial 16S rRNA or 16S rRNA gene sequences derived from DGGE or SSCP bands (Fig. 4); 55\% of these belonged to Phylum Proteobacteria, covering all major groups (Fig. 5), $24 \%$ to Phylum Bacteroidetes (Fig. 6), $7 \%$ to Class Actinobacteria, 5\% to Phylum Cyanobacteria, $2 \%$ were distantly related to the genus Nitrospina (Fig. 7) and 5\% were identified as Phylum Crenarchaeota (Fig. 8). Band FD 36 (Fig. 7) could not be affiliated with a special taxonomic group.

The depth distribution of all microorganisms identified using this approach is shown in Fig. 9; $25 \%$ of these microorganisms were detected on a DNA as well as on an RNA level by SSCP fingerprinting (Fig. 9). Only Bands FD 4, FD 17 and FD 27, representing $10 \%$ of the investigated community based on $16 \mathrm{~S}$ rRNA, were detected by both primer systems and fingerprinting methods used (Fig. 9B).

\section{Depth distribution of microorganisms}

The relative 16S rRNA abundance of the 3 PCR products that were detected by both methods, SSCP and DGGE, was calculated by determining relative band intensities. Based on this quantification

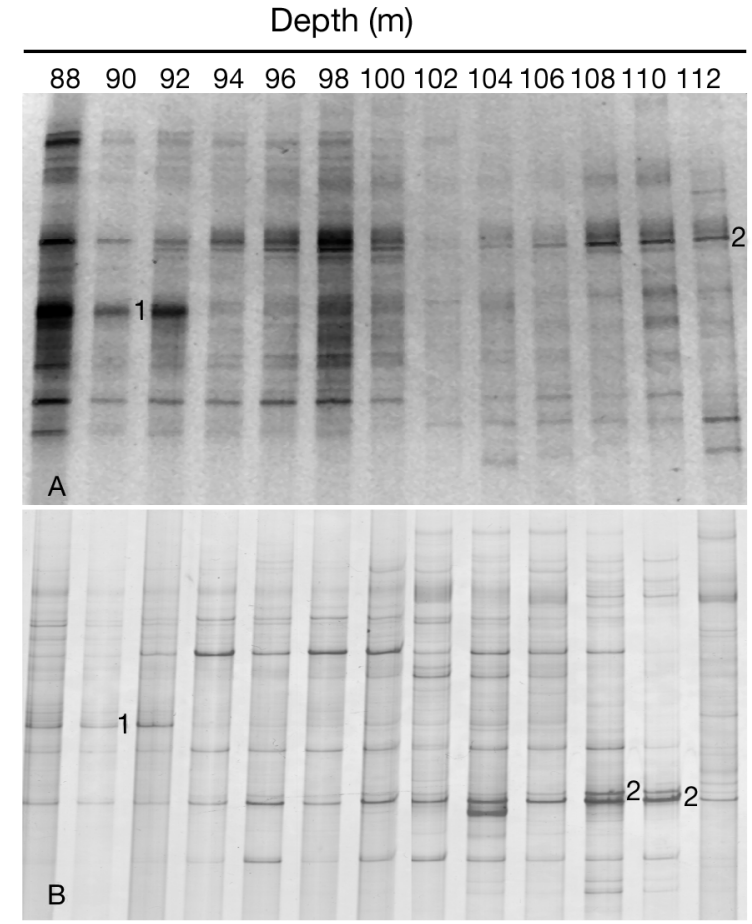

Fig. 4. 16S rcDNA fingerprinting profiles of the redoxcline of Fårö Deep Stn 286 in August 2003: (A) DGGE; (B) single strand conformation polymorphism (SSCP). 1: Band FD 27 (Pseudoalteromonas sp. D41); 2: Band FD 17 (uncultured Helicobacteraceae G138eps1) 


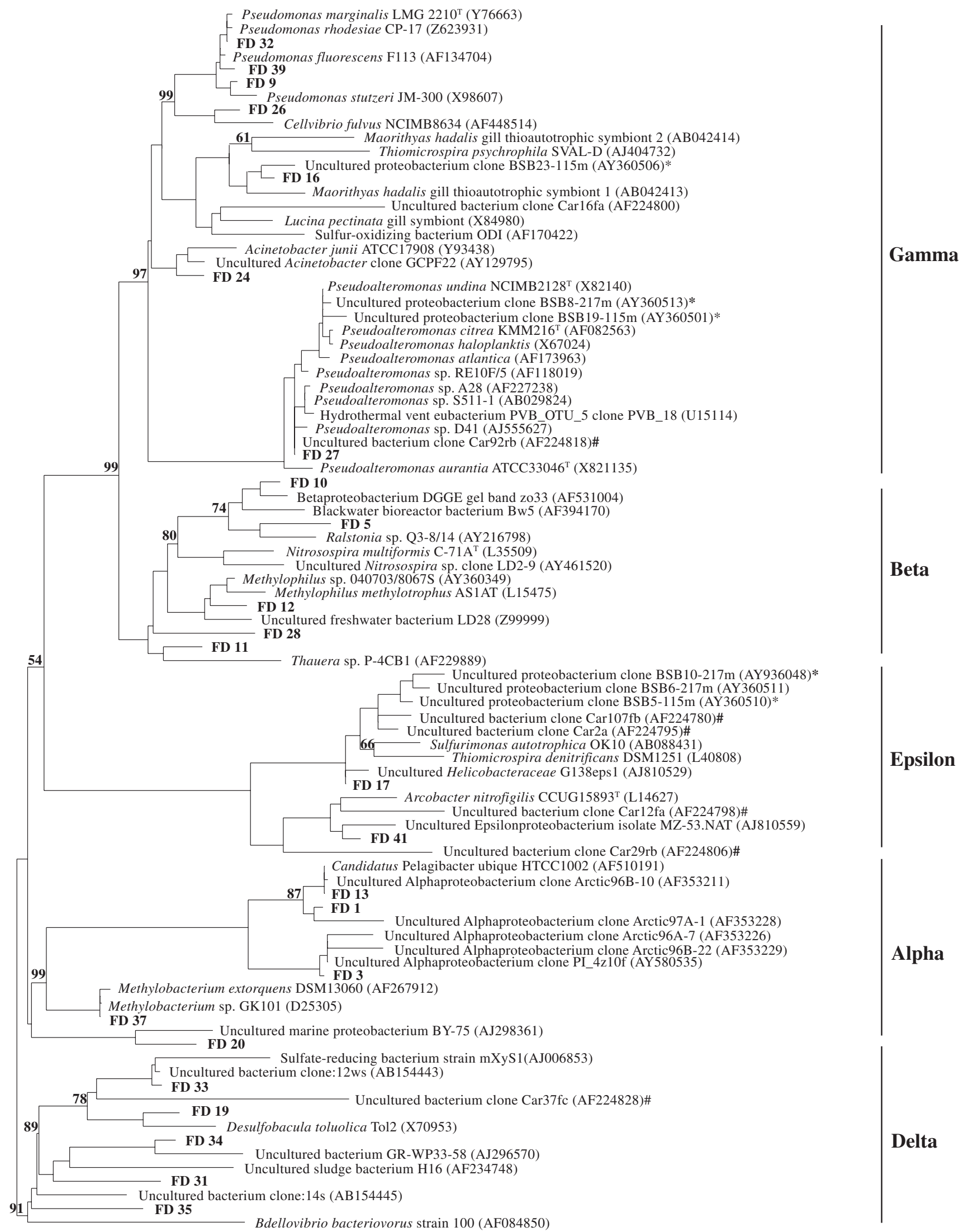

0.10 
Fig. 5. Unrooted tree showing phylogenetic relationships of identified Proteobacteria and their closest phylogenetic relatives. GenBank accession numbers given in parentheses. For tree reconstruction, 10 members of Sphingobacteriaceae were used as an outgroup. Bootstrap values above $50 \%$ are shown. Bar: 10 substitutions per $100 \mathrm{nt}$. More detailed information on investigated sequences given in Fig. 9. ${ }^{*}$ Detected in the Black Sea (Vetriani et al. 2003); ${ }^{\#}$ Detected in Cariaco Basin (Madrid et al. 2001)

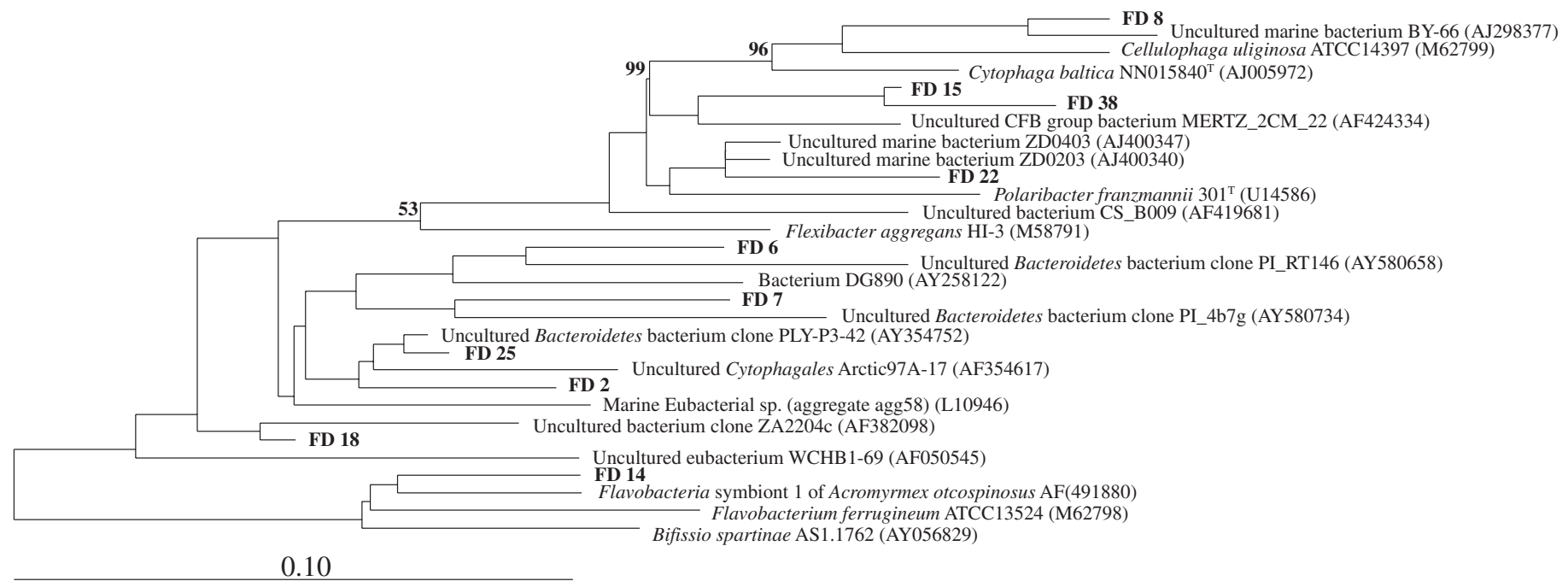

Fig. 6. Unrooted tree showing phylogenetic relationships of identified Bacteroidetes and their closest phylogenetic relatives. GenBank accession numbers given in brackets. For tree reconstruction, 23 members of Chlorobi were used as an outgroup. Bootstrap values above $50 \%$ are shown. Bar: 10 substitutions per $100 \mathrm{nt}$. More detailed information on investigated sequences given in Fig. 9

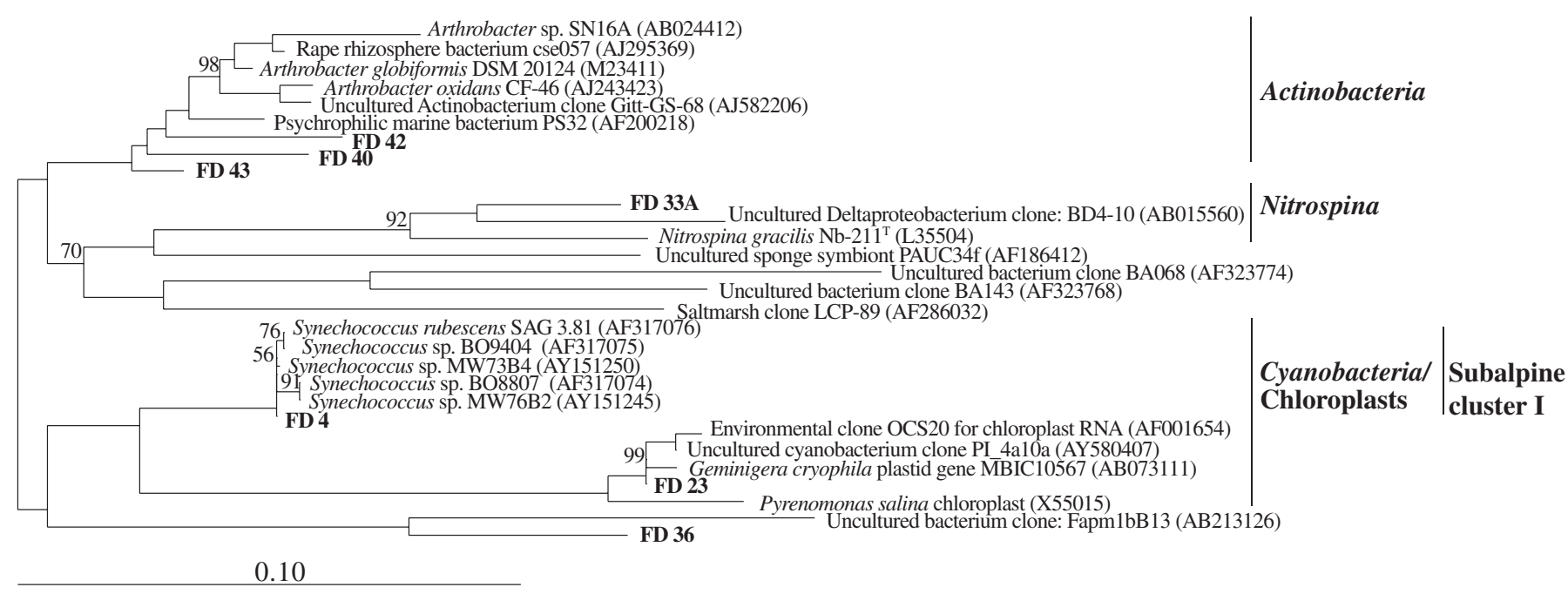

Fig. 7. Unrooted tree showing phylogenetic relationships of identified Cyanobacteria, Nitrospina and Actinobacteria and their closest phylogenetic relatives. GenBank accession numbers given in brackets. For tree reconstruction, 12 members of Acidimicrobiaceae were used as an outgroup. Bootstrap values above $50 \%$ are shown. Bar: 10 substitutions per 100 nt. More detailed information on investigated sequences given in Fig. 9 


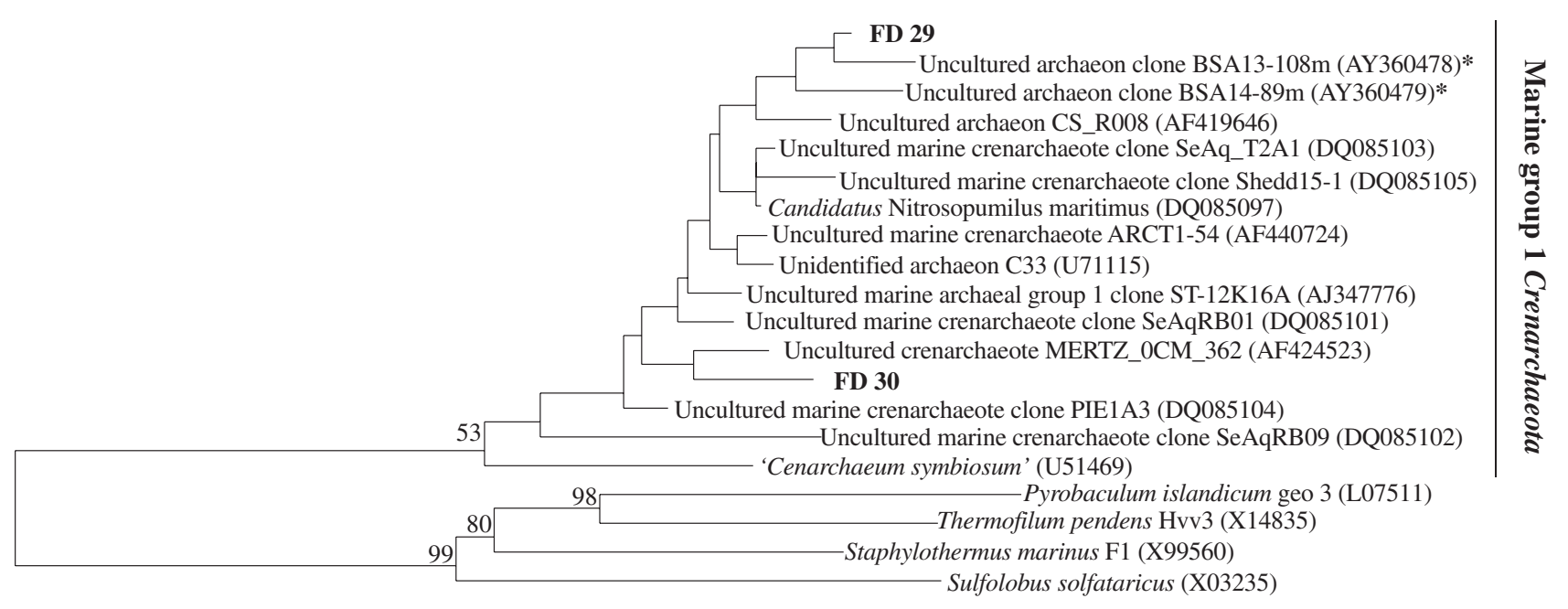

0.10

Fig. 8. Unrooted tree showing phylogenetic relationships of identified Crenarchaeota and their closest phylogenetic relatives. GenBank accession numbers given in brackets. For tree reconstruction, 10 Pyrococcus spp. were used as an outgroup. Bootstrap values above $50 \%$ are shown. Bar: 10 substitutions per $100 \mathrm{nt}$. More detailed information on investigated sequences given in Fig. 9. ${ }^{*}$ Detected in the Black Sea (Vetriani et al. 2003)

approach, each of the three $16 \mathrm{~S}$ rRNAs was dominant in different layers of the water profile. Moreover, at least $20 \%$ of the $16 \mathrm{~S}$ rRNA detectable by our approach was mostly covered by 1 of these sequences (Fig. 10). Synechococcus Band FD 4 (Fig. 7) was dominant in surface water, decreasing in relative abundance from approximately 30 to $80 \%$ at $2 \mathrm{~m}$ to $5 \%$ at $60 \mathrm{~m}$. Pseudoalteromonas Band FD 27 (Fig. 5) was detected from the beginning of the salinity increase and oxygen decrease area (60 to $75 \mathrm{~m}$ depth) down to the lowest depth were oxygen was still measurable (104 m depth); however, highest occurrence was from 60 to $92 \mathrm{~m}$ depth within the nitrate peak (Fig. 2B). Epsilonproteobacterium Band FD 17 (Fig. 5) appeared first at the suboxic zone at $92 \mathrm{~m}$ depth, obtained its relative maximum in the area of nitrate disappearance and initial sulfide appearance (110 m depth), and was subsequently continuously present with abundances of approximately $20 \%$ in the sulphidic zone.

At similar depths detected using 16S rRNA SSCP and DGGE, Bands FD 4 and FD 17 were detected on a DNA basis using SSCP fingerprinting (Fig. 9). Alphaproteobacterium Band FD 3 (Fig. 5) was equally present on a DNA and RNA basis between 2 and $75 \mathrm{~m}$ depth. 16S rRNA of the Gammaproteobacterium Band FD 16 (Fig. 5) was firstly detected at $75 \mathrm{~m}$ depth, and its RNA together with DNA from 100 to $180 \mathrm{~m}$ depth. 16S rRNA genes of Desulfobacula Band FD 19 were detected from 110 to $160 \mathrm{~m}$ depth, but Band FD 19 16S rRNA was only detected from 110 to $120 \mathrm{~m}$.

\section{DISCUSSION}

\section{Applicability of the fingerprint approach}

We used 16S rRNA based community SSCP and DGGE fingerprints in addition to DNA based community fingerprints to facilitate the identification of potentially abundant bacterial assemblages in the water column, because RNA reflects actively growing bacteria better than DNA does. A major advantage of these fingerprint techniques was that we were able to obtain an immediate overview of the microbial structure that should have been present at a concentration of at least $1 \%$ (Muyzer et al. 1993). However, we were predominantly interested in the vertical distribution of the abundant and potentially active prokaryotes and their relation to the physico-chemical structures of the water column. Thus, we usually applied a 16S rRNA based fingerprinting approach, which provided information about the potentially active members of microbial assemblages. However, PCR-based fingerprints are biased by the primers selected and the PCR itself (von Wintzingerode et al. 1997). Therefore, different primer combinations, or several different primer sets, should be considered in order to obtain better prokaryotic taxon coverage, especially when low amounts of PCR template are applied (Webster et al. 2003). Our approach was based on the 2 fingerprint systems SSCP and DGGE, using 2 different primer systems based on 3 different primers. Similar approaches have been 
A

$\begin{array}{ll}\begin{array}{l}\text { Fingerprint } \\ \text { band ID }\end{array} & \begin{array}{l}\text { GenBank } \\ \text { accession no }\end{array}\end{array}$ Closest phylogenetic relative

Depth (m)

\begin{tabular}{|c|c|c|}
\hline FD 1 & DQ385019 & Uncultured Alphaproteobacterium clone Arctic97A-1 \\
\hline FD 2 & DQ385024 & Bacterium DG890 \\
\hline FD 3 & DQ385048 & Uncultured Alphaproteobacterium clone Arctic96B-22 \\
\hline FD 4 & DQ385044 & Synechococcus sp. MW73B4 \\
\hline FD 5 & DQ385027 & Ralstonia sp. Q3-8/14 \\
\hline FD 6 & DQ385026 & Uncultured Bacteroidetes clone PI_RT146 \\
\hline FD 7 & D0385025 & Uncultured Bacteroidetes clone PI_-4b7g \\
\hline FD 8 & D0385021 & Uncultured marine bacterium BY-66 \\
\hline FD 9 & DQ385022 & Pseudomonas stutzeri \\
\hline FD 10 & DQ385015 & Betaproteobacterium zo33 \\
\hline FD 11 & DQ385016 & Thauera sp. P-4CB1 \\
\hline FD 12 & DQ385017 & Methylophilus sp. 040703/8067S \\
\hline FD 13 & DQ385018 & Candidatus Pelagibacter ubique \\
\hline FD 14 & DQ385023 & Flavobacteria symbiont 1 of Acromyrmex otcospinosus \\
\hline FD 15 & DQ385020 & Polaribacter franzmannii \\
\hline FD 16 & DQ385035 & Maorithyas hadalis gill thioautotrophic symbiont \\
\hline FD 17 & DQ385052 & Uncultured Helicobacteraceae G138eps1 \\
\hline FD 18 & D0385029 & Uncultured Bacteroidetes clone ZA220c \\
\hline FD 19 & DQ385028 & Desulfobacula toluolica \\
\hline
\end{tabular}

\begin{tabular}{llllllllllllll}
\cline { 2 - 9 } & 2 & 15 & 25 & 40 & 60 & 75 & 85 & 100 & 110 & 120 & 140 & 160 & 180 \\
\hline
\end{tabular}

B

DQ385028

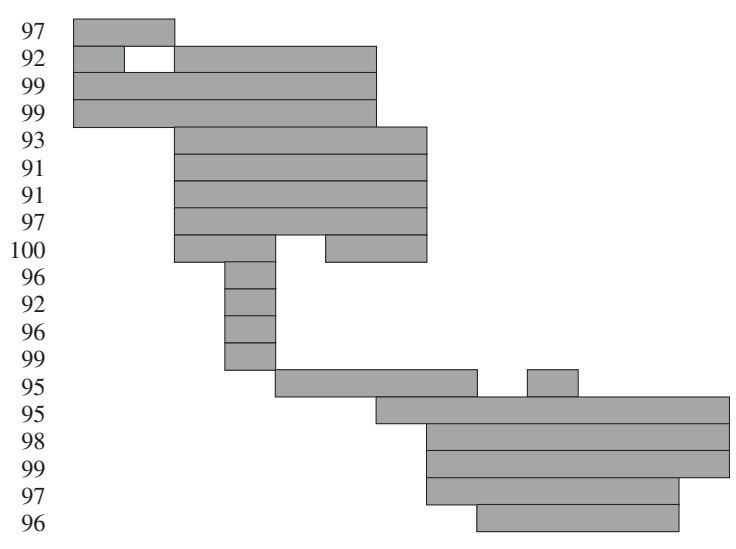

Fingerprint GenBank band ID accession no.

Closest phylogenetic relative

Depth (m)

\begin{tabular}{|c|c|c|}
\hline FD 20 & DQ385045 & Uncultured marine proteobacterium BY-75 \\
\hline FD 4 & DQ385044 & Synechococcus sp. MW73B4 \\
\hline FD 3 & DQ385048 & Uncultured Alphaproteobacterium clone Arctic96B-2 \\
\hline FD 22 & DQ385049 & Uncultured marine bacterium ZD0203 \\
\hline FD 23 & DQ385047 & Uncultured cyanobacterium clone PI_4a10a \\
\hline FD 24 & DQ385032 & Uncultured Acinetobacter clone GCPF22 \\
\hline FD 25 & DQ385046 & Uncultured Bacteroidetes bacterium clone PLY-P3-42 \\
\hline FD 26 & DQ385030 & Cellvibrio fulvus NCIMB 8634 \\
\hline FD 27 & DQ385050 & Pseudoalteromonas sp. D41 \\
\hline FD 28 & DQ385031 & Uncultured Nitrosospira clone LD2-9 \\
\hline FD 16 & DQ385035 & Maorithyas hadalis gill thioautotrophic symbiont \\
\hline FD 29 & DQ385014 & Uncultured marine crenarchaeote ARCT1-54 \\
\hline FD 30 & DQ385038 & Uncultured crenarchaeote MERTZ_0CM_362 \\
\hline FD 17 & DQ385052 & Uncultured Helicobacteraceae G138eps1 \\
\hline FD 31 & DQ385037 & Uncultured bacterium clone: $14 \mathrm{~s}$ \\
\hline FD 32 & DQ385051 & Pseudomonas rhodesiae strain $\mathrm{CP}-17$ \\
\hline FD 19 & DQ385028 & Desulfobacula toluolica \\
\hline FD 33 & DQ385053 & Uncultured bacterium clone: $12 \mathrm{ws}$ \\
\hline
\end{tabular}

DQ385053

Uncultured bacterium clone: 12 ws

$\begin{array}{lll}\text { FD 32 } & \text { DQ385051 } & \text { Pseudomonas rhodesiae } \text { strain CP-17 } \\ \text { FD 33A } & \text { DQ385054 } & \text { Uncultured Deltaproteobacterium JL-ETNP-Z23 } \\ \text { FD 34 } & \text { DQ385056 } & \text { Uncultured bacterium GR-WP33-58 } \\ \text { FD 13 } & \text { DQ385018 } & \text { Candidatus } \text { Pelagibacter ubique } \\ \text { FD 31 } & \text { DQ385037 } & \text { Uncultured bacterium clone:14s } \\ \text { FD 35 } & \text { DQ385039 } & \text { Lucina pectinata } \text { symbiont } \\ \text { FD 27 } & \text { DQ385050 } & \text { Pseudoalteromonas } \text { sp. D41 } \\ \text { FD 36 } & \text { DQ385033 } & \text { Uncultured bacterium clone:Fapm1bB13 } \\ \text { FD 23 } & \text { DQ385047 } & \text { Uncultured cyanobacterium clone PI_4a10a } \\ \text { FD 37 } & \text { DQ385055 } & \text { Methylobacterium } \text { sp. GK101 } \\ \text { FD 16 } & \text { DQ385035 } & \text { Maorithyas } \text { hadalis } \text { gill thioautotrophic symbiont } \\ \text { FD 30 } & \text { DQ385038 } & \text { Uncultured crenarchaeote MERTZ_OCM_362 } \\ \text { FD 17 } & \text { DQ385052 } & \text { Uncultured } \text { Helicobacteraceae } \text { G138eps1 } \\ \text { FD 38 } & \text { DQ385043 } & \text { Uncultured CFB group bacterium MERTZ_2CM_22 } \\ \text { FD 39 } & \text { DQ385034 } & \text { Pseudomonas fluorescens } \\ \text { FD 40 } & \text { DQ385040 } & \text { Uncultured Actinobacterium clone Gitt-GS-68 } \\ \text { FD 41 } & \text { DQ385036 } & \text { Uncultured Epsilonproteobacterium isolate MZ-53.NAT } \\ \text { FD 18 } & \text { DQ385029 } & \text { Uncutured bacterium clone ZA2204c } \\ \text { FD 19 } & \text { DQ385028 } & \text { Desulfobacula toluolica } \\ \text { FD 42 } & \text { DQ385041 } & \text { Uncultured Actinobacterium clone Gitt-GS-68 } \\ \text { FD 43 } & \text { DQ385042 } & \text { Rape rhizosphere bacterium cse057 }\end{array}$

\begin{tabular}{llllllllllllll} 
(\%) & 2 & 15 & 25 & 40 & 60 & 75 & 85 & 100 & 110 & 120 & 140 & 160 & 180 \\
\hline
\end{tabular}
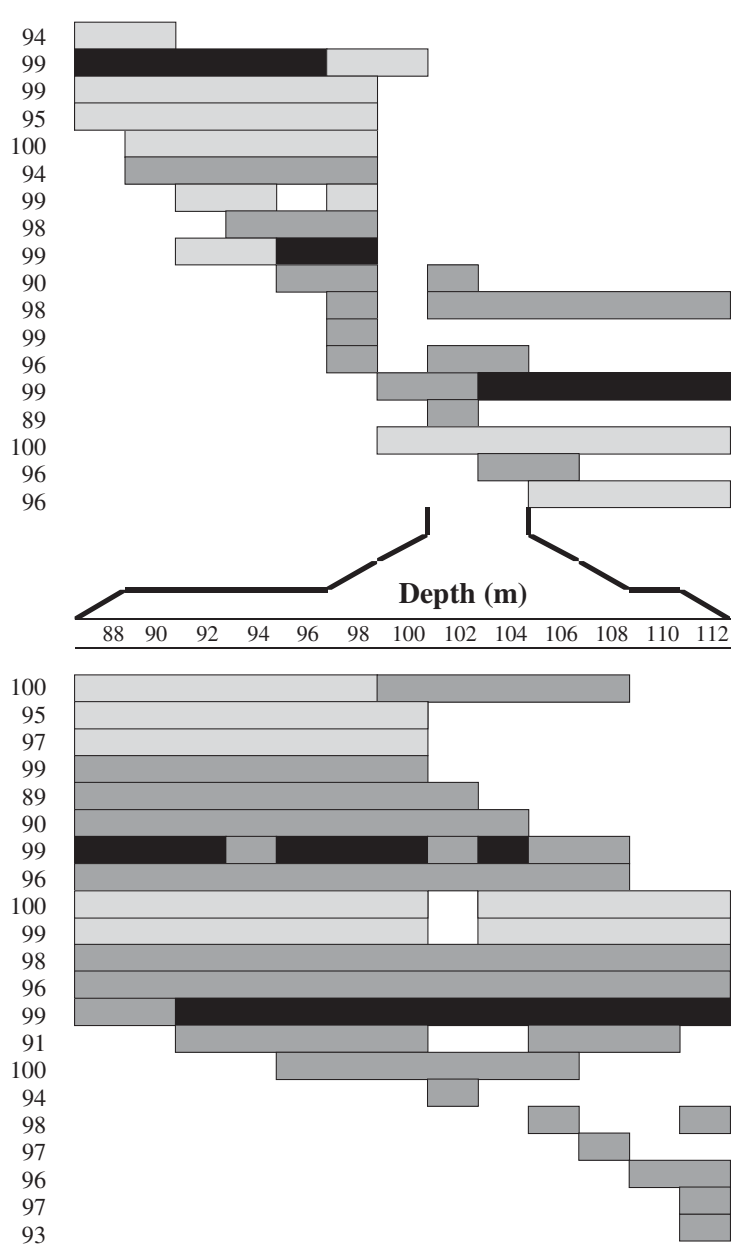

Determined by SSCP analyses

Determined by both fingerprinting methods

Determined by DGGE anyalalyses

Fig. 9. Depth distribution of identified taxa based on (A) 16S rRNA gene single strand conformation polymorphism (SSCP) fingerprinting and (B) 16S rcDNA SSCP and DGGE fingerprinting. The extended redoxcline is displayed (B, lower section). 


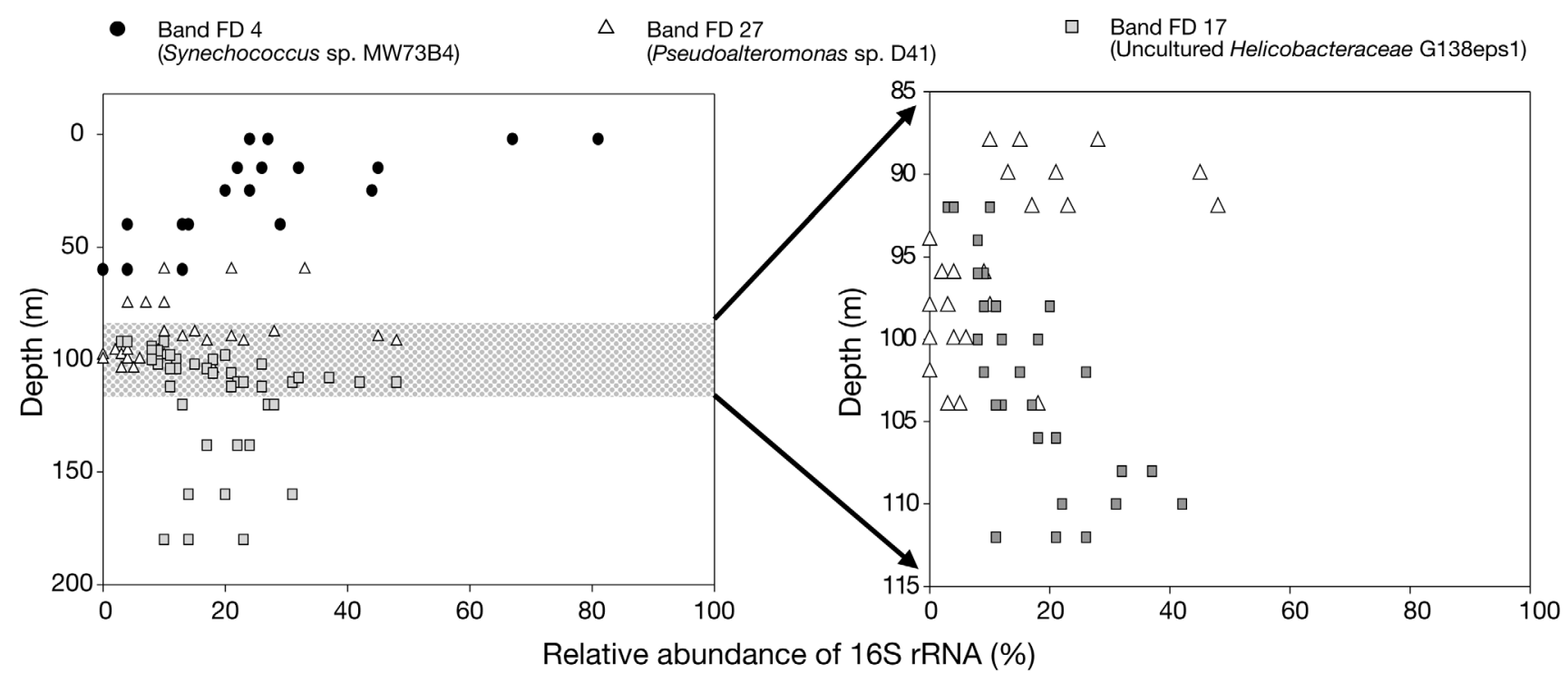

Fig. 10. Relative abundance of bacterial 16S rRNA identified by both fingerprinting methods (SSCP and DGGE). Shaded area denotes the redoxcline, shown in detail on the right

applied previously. For instance, both fingerprinting techniques were used to investigate prokaryotic succession patterns in a methanogenic reactor (Hori et al. 2006). Hori et al. (2006) found similar archaeal but different bacterial SSCP and DGGE patterns. In our study, both methods were deemed suitable to describe shifts in relative community compositions along the physico-chemical structures of the water column in the Fårö Deep (Figs. 4 \& 9), but they nevertheless revealed some differences concerning the abundant organisms.

16S rRNA SSCP or DGGE bands with sequence similarities of $\geq 98 \%$ were taxonomically grouped together. A grouping of these partial sequences was possible because the bacterial Com-primers (which amplify positions 519 to 926 of E. coli numbering; Schwieger \& Tebbe 1998) and bacterial primers 341F-GC and 907R (which amplify positions 341 to 926 of E. coli numbering; Muyzer et al. 1995) amplify comparable regions of the 16S rRNA, and principally share the reverse primer (except that the original $\mathrm{R}$ at Position 921 is reduced to $\mathrm{G}$ in the SSCP primer). Only 3 species could be allocated to distinct zones of the water column using both 16S rRNA fingerprinting methods: Synechococcus Band FD 4, Pseudoalteromonas Band FD 27 and Epsilonproteobacterium band FD 17 (Fig. 10), representing about $10 \%$ of the community members detected by this approach (Fig. 9B). However, the relative 16S rRNA abundance of those sequences that were detected by both methods mostly accounted for at least $20 \%$ of all 16S rRNA (Fig. 10). Presumably, other microorganisms were not detected by both systems because of different primer selections. However, the nearly whole 16S rRNA of an Epsilon- proteobacterium Band FD 17 clone was sequenced (J. Grote et al. unpubl. data), demonstrating that the reverse primers 907R/Com2-Ph (Muyzer et al. 1995, Schwieger \& Tebbe 1998) hybridized even with 1 mismatch (A instead of T, Position 921, E. coli numbering) against Band FD 17. In contrast, Band FD 16 (99\% 16S rRNA sequence similarity to Maorithyas hadalis gill thioautotrophic symbiont) was detected on a DNA and RNA basis by the SSCP primer system, but not by the DGGE primers (Fig. 9), despite the fact that its closest relative was detected by the DGGE primers without any mismatch. Although this could be due to strainspecific sequence differences, it seems more probable that the presence and activity of these 2 organisms was overestimated by the SSCP system. In summary, the 3 bacteria species discussed above were considered to be not only abundant but also active.

\section{Appropriateness of phylogenetic identification}

The following bacteria corresponding to derived sequences were often phylogenetically very close relatives (98 to $99 \%$ sequence similarity) to organisms (in parentheses) with distinct physiological properties, and might therefore share their basic physiology: Band FD 4 (photoautotrophic Synechococcus sp. MW73B4), Band FD 16 (Maorithyas hadalis gill thioautotrophic symbiont), Band FD 17 (chemolithoautotrophic uncultured Helicobacteraceae G138eps1) and Band FD 27 (heterotrophic Pseudoalteromonas sp. D41) (Fig. 9). Physiological capacities of the uncultured Alphaproteobacterium clone Arctic96B-22 (Band FD 3) are 
unknown, but it was described as a member of a bacterioplankton assemblage (Bano \& Hollibaugh 2002). Normally, information on the structure of bacterial communities based on phylogenetic relationships does not reveal any trait of their physiological properties. However, the above-mentioned strains were highly related to physiologically defined phylogenetic clusters, thus allowing some conclusions on their general properties to be drawn.

Band FD 19 was phylogenetically closely related to the autotrophic ammonium oxidizing Candidatus Nitrosopumilus maritimus, a member of the Marine Group 1 Crenarchaeota (Fig. 8) (Könneke et al. 2005). The low bootstrap confidence for branchings could have been due to rapid succession in this clade. The appearance of Band FD 19 in the nitrate and nitrite maximum of the water column (Fig. 2) could indicate that its physiology is similar to that described for Candidatus N. maritimus (Könneke et al. 2005). However, the importance of Archaea within the water column of the central Baltic Sea is still unclear, and our system was not specifically designed to analyse Archaea. Only about $50 \%$ of the Archaea included in the recent phylogenetic ARB database can be detected by the Com-primer system used for SSCP analyses (Schmalenberger et al. 2001).

\section{Synechococcus Band FD 4}

Based on flow cytometric analyses, the phototrophic picocyanobacteria cell concentration in the photic zone was approximately $5 \%$ of total prokaryotic cell numbers (Fig. 3). Compared to this, 16S rRNA concentrations of Synechococcus Band FD 4 (in the range of 30 to $80 \%$ ) were much higher (Fig. 10). This might be an indicator for a high activity level of Synechococcus cells accompanying a blooming situation in August 2003. It has been shown that small-sized Synechococcus sp. can be abundant in summer cyanobacterial blooms in the Baltic Proper (Stal et al. 2003). Phylogenetically, Synechococcus Band FD 4 was $99 \%$ identical to several freshwater Synechococcus isolates, e.g. to MW73B4 (Fig. 7), which was originally isolated from the oligo-mesotrophic, deep subalpine Lake Hallstättersee (Crosbie et al. 2003). In general, our detected sequence belonged to the Subalpine Cluster I, for which phycoerythrin-rich Synechococcus rubescens SAG B3.81 was suggested as the type strain (Ernst et al. 2003). The occurrence of this freshwater Synechococcus would not be exceptional because the Baltic Sea, with its distinct vertical and horizontal salinity gradients, allows the co-existence of species of both freshwater and marine origin (Paavola et al. 2005). In fact, the photic zone of the central Baltic Sea seemed to be more suitable for freshwater picocyanobacteria than for marine species. This would be in agreement with other data concerning phytoplankton composition, e.g. the western border of the Baltic Proper, Darss Sill (mean salinity $10 \%$ ), was declared as the most important biological border in the Baltic Sea (Kell 1973, Wasmund et al. 2004, Witkowski et al. 2005). Marine species dominated westward and limnetic species eastward of it.

Interestingly, the picocyanobacteria concentration increased again in the sulphidic zone to nearly $10^{4}$ cells ml ${ }^{-1}$ (Fig. 3). This phenomenon was observed previously, and a heterotrophic lifestyle was suggested for these picocyanobacteria (Detmer et al. 1993). Synechococcus Band FD 4 was not detected in this zone by our fingerprinting approach, despite even higher cell numbers compared with concentrations in winter water (Fig. 3). This could be an indicator of the inactivity of these cells, or flow cytometric analyses detected different picocyanobacteria assemblages in the sulphidic zone.

\section{Pseudoalteromonas Band FD 27}

16S rRNA of Pseudoalteromonas Band FD 27 was detected throughout the whole suboxic area (Figs. 9B $\& 10)$. It has been shown that isolates related to the common heterotrophic genus Pseudoalteromonas readily colonize and degrade chitinous particles (Baty et al. 2000). Thus, it could be speculated that potentially heterotrophic Band FD 27 could have been stimulated by marine snow. Strains of Pseudoalteromonas have been repeatedly described as algicidal bacteria (Skerratt et al. 2002, Giovannoni \& Stingl 2005), and it is known that Gammaproteobacteria can be dominant colonizers of marine snow aggregates (Simon et al. 2002). However, it is unclear if these characters are also valid for FD 27.

\section{Epsilonproteobacterium Band FD 17}

Epsilonproteobacterium Band FD 17 was phylogenetically $99 \%$ similar to the uncultured Helicobacteraceae G138eps1, a potential autotrophic nitratereducing bacterium enriched from pelagic redoxclines of the Gotland Deep in September 1998 ( Brettar et al. 2006) and the Landsort Deep in August 2004 (Labrenz et al. 2005), both sites located in the central Baltic Sea. In 1998, quantified by real-time PCR, this organism was present at the redoxcline in concentrations of approximately $8 \%$ of total bacterial numbers and, in deeper areas $(175 \mathrm{~m})$, at concentrations of up to $15 \%$ (Labrenz et al. 2004). Interestingly enough, these concentrations 
are comparable to the relative $16 \mathrm{~S}$ rRNA quantifications based on our fingerprint approach (Fig. 10). The abundance at highly sulphidic and nitrate-free deeper zones of the Gotland as well as of the Fårö Deep could indicate a potentially diverse metabolism of this organism. However, as previously shown for uncultured Helicobacteraceae G138eps1, the ribosomal content per cell decreased with depth, indicating highest activity level at the redoxcline (Labrenz et al. 2004).

\section{Comparability with other anoxic marine basins}

Differences in the vertical distribution of pelagic microorganisms with different preferences have already been demonstrated for oxic (Gordon \& Giovannoni 1996, Giovannoni \& Stingl 2005), suboxic (Fuchs et al. 2005), and particularly for oxic/anoxic water columns (Ramsing et al. 1996, Teske et al. 1996). In order to compare the microbial diversity of the central Baltic Sea with other anoxic marine waters, one has to distinguish between organisms of local and more general importance. Based on the above-described microbial distribution in the water column in August 2003, the 16S rRNA dominance of Synechococcus Band FD 4 in the photic zone of low salinity (Fig. 10) can be assessed as specific to the Baltic, because extensive blooms in brackish waters are known almost exclusively from the Baltic Sea (Bianchi et al. 2000).

Close phylogenetic relatives of Pseudoalteromonas Band FD 27 have been detected in the Black Sea at depths with comparable geochemical conditions (Vetriani et al. 2003) and also in the anoxic zone of the Cariaco Basin (Madrid et al. 2001). Pseudoalteromonas spp. are ubiquitous in marine pelagic environments. However, it is interesting to note that most Pseudoalteromonas spp. detected in all 3 deeps clustered together, and were phylogenetically closely related to $P$. atlantica and $P$. undina (Fig. 5). Pseudoalteromonas spp. are generally psychro-tolerant, and it could be speculated that the presence of this cluster (at least in the Baltic and Black Sea; Jørgensen et al. 1991) was due to stable lower temperatures below the halocline (Fig. 2A). A similar situation (but one that is probably more closely correlated with the presence of ammonium and oxygen) is evident for Band FD 19, which belongs to the Marine Group 1 Crenarchaeota (Fig. 8). Close relatives of this marine organism were also detected in the Black Sea, again in comparable habitats (Vetriani et al. 2003).

Naturally, the pelagic redoxclines are characteristic and important zones for anaerobic marine deeps. Chemolithoautotrophic bacteria seem to play a major role in these habitats. Close phylogenetic relatives of the Maorithyas hadalis gill thioautotrophic symbiont were detected in the redoxcline of the central Baltic Sea (Figs. 5 \& 9B) as well as in the Black Sea (Vetriani et al. 2003). Based on stimulation experiments, it was previously postulated that at the oxic-anoxic interfaces of the Gotland Deep, an Epsilonproteobacterium that is related to Thiomicrospira denitrificans (recently reclassified as Sulfurimonas denitrificans; Takai et al. 2006) could be a key organism involved in autotrophic nitrate reduction (Brettar et al. 2006). Moreover, Lin et al. (2006) detected high concentrations of Epsilonproteobacteria in pelagic redoxclines of the Black Sea and Cariaco Basin. When comparing the redoxclines of the central Baltic Sea, Black Sea and Cariaco Basin, it is evident that chemolithoautotrophic sulphur-oxidizing Epsilonproteobacteria belonging to the Sulfurimonas spp. cluster (Figs. 5 \& 10) (Madrid et al. 2001, Vetriani et al. 2003) are important members of their respective microbial assemblages in these zones, thus confirming their recently postulated overall relevance to sulphidic habitats (Campbell et al. 2006).

Acknowledgements. We are grateful to the captain and crew of RV 'Alexander von Humboldt'. The excellent technical assistance of Heike Brockmöller, Bärbel Buuk and Annett Grüttmüller is greatly appreciated. Special thanks to Norbert Wasmund for helpful discussion and for providing literature. This work was funded by the Leibniz-Institut für Ostseeforschung Warnemünde.

\section{LITERATURE CITED}

Altschul SF, Madden TL, Schäffer AA, Zhang J, Zhang Z, Miller W, Lipman DJ (1997) Gapped BLAST and PSIBLAST: a new generation of protein database search programs. Nucleic Acids Res 25:3389-3402

Bano N, Hollibaugh JT (2002) Phylogenetic composition of bacterioplankton assemblages from the Arctic Ocean. Appl Environ Microbiol 68:505-518

Baty AM, III, Eastburn CC, Diwu Z, Techkarnjanaruk S, Goodman AE, Geesey GG (2000) Differentiation of chitinase-active and non-chitinase-active subpopulations of a marine bacterium during chitin degradation. Appl Environ Microbiol 66:3566-3573

Bauer S (2003) Structure and function of nitrifying bacterial communities in the eastern Gotland basin (central Baltic Sea). $\mathrm{PhD}$ thesis, Universität Rostock

Bianchi TS, Engelhaupt E, Westman P, Andrén T, Rolff C, Elmgren R (2000) Cyanobacterial blooms in the Baltic Sea: Natural or human-induced? Limnol Oceanogr 45:716-726

Bölter M, Rheinheimer G (1987) Numerical analysis of microbial and chemical characters and of saprophytic bacteria from the Baltic Sea. Bot Mar 30:535-544

Brettar I, Moore ERB, Höfle MG (2001) Phylogeny and abundance of novel denitrifying bacteria isolated from the water column of the central Baltic Sea. Microb Ecol 42:295-305

Brettar I, Labrenz M, Flavier S, Bötel J, Kuosa H, Christen R, Höfle MG (2006) Identification of a Thiomicrospira denitrificans-like Epsilonproteobacterium as a catalyst for autotrophic denitrification in the central Baltic Sea. Appl Environ Microbiol 72:1364-1372 
Campbell BJ, Summers Engel A, Porter ML, Takai K (2006) The versatile $\varepsilon$-proteobacteria: key players in sulphidic habitats. Nat Rev Microbiol 4:458-468

Crosbie ND, Pockl M, Weisse T (2003) Dispersal and phylogenetic diversity of nonmarine picocyanobacteria, inferred from 16S rRNA gene and $c p c B A$-intergenic spacer sequence analyses. Appl Environ Microbiol 69:5716-5721

Detmer AE, Giesenhagen HC, Trenkel VM, Venne HAD, Jochem FJ (1993) Phototrophic and heterotrophic pico- and nanoplankton in anoxic depths of the central Baltic Sea. Mar Ecol Prog Ser 99:197-203

Ernst A, Becker S, Wollenzien UIA, Postius C (2003) Ecosystem-dependent adaptive radiations of picocyanobacteria inferred from 16S rRNA and ITS-1 sequence analysis. Microbiology 149:217-228

Fuchs BM, Woebken D, Zubkov MV, Burkill P, Amann R (2005) Molecular identification of picoplankton populations in contrasting waters of the Arabian Sea. Aquat Microb Ecol 39:145-157

Gasol JM, Casamayor EO, Joint I, Garde K and 6 others (2004) Control of heterotrophic prokaryotic abundance and growth rate in hypersaline planktonic environments. Aquat Microb Ecol 34:193-206

Giovannoni SJ, Stingl U (2005) Molecular diversity and ecology of microbial plankton. Nature 437:343-348

Gordon DA, Giovannoni SJ (1996) Detection of stratified microbial populations related to Chlorobium and Fibrobacter species in the Atlantic and Pacific oceans. Appl Environ Microbiol 62:1171-1177

Grasshoff K, Erhardt M, Kremling K (1983) Methods of seawater analysis, 2nd edn. Verlag Chemie, Weinheim

Höfle MG, Brettar I (1995) Taxonomic diversity and metabolic activity of microbial communities in the water column of the Central Baltic Sea. Limnol Oceanogr 40:868-874

Höfle MG, Brettar I (1996) Genotyping of heterotrophic bacteria from the central Baltic Sea by use of low-molecular-weight RNA profiles. Appl Environ Microbiol 62: 1383-1390

Hori T, Haruta S, Ueno Y, Ishii M, Igarashi Y (2006) Direct comparison of single-strand conformation polymorphism (SSCP) and denaturing gradient gel electrophoresis (DGGE) to characterize a microbial community on the basis of 16S rRNA gene fragments. J Microbiol Methods 66: 165-169

Jørgensen BB, Fossing H, Wirsen CO, Jannasch HW (1991) Sulfide oxidation in the anoxic Black Sea chemocline. Deep-Sea Res 38:S1083-S1103

Kell V (1973) Die Darßer Schwelle — eine biologische Grenze? Wiss Z Univ Rostock 22:617-623

Könneke M, Bernhard AE, de la Torre JR, Walker CB, Waterbury JB, Stahl DA (2005) Isolation of an autotrophic ammonia-oxidizing marine archaeon. Nature 437:543-546

Labrenz M, Brettar I, Christen R, Flavier S, Bötel J, Höfle MG (2004) Development and application of a real-time PCR approach for quantification of uncultured bacteria in the central Baltic Sea. Appl Environ Microbiol 70:4971-4979

Labrenz M, Jost G, Pohl C, Beckmann S, Martens-Habbena W, Jürgens K (2005) Impact of varying in vitro electron donator/-acceptor conditions on potential chemolithoautotrophic communities from marine pelagic redoxclines. Appl Environ Microbiol 71:6644-6672

Lane DJ (1991) 16S/23S rRNA Sequencing. In: Stackebrandt E, Goodfellow M (eds) Nucleic acid techniques in bacterial systematics. John Wiley \& Sons, Chichester, p 115-175

Lin X, Wakeham SG, Putnam IF, Astor YM, Scranton MI, Chistoserdov AY, Taylor GT (2006) Comparison of vertical distributions of prokaryotic assemblages in the anoxic
Cariaco Basin and Black Sea by use of fluorescence in situ hybridization. Appl Environ Microbiol 72:2679-2690

Ludwig W, Strunk O, Westram R, Richter L and 28 others (2004) ARB: a software environment for sequence data. Nucleic Acids Res 32:1363-1371

Madrid VM, Taylor GT, Scranton MI, Chistoserdov AY (2001) Phylogenetic diversity of bacterial and archaeal communities in the anoxic zone of the Cariaco Basin. Appl Environ Microbiol 67:1663-1674

Muyzer G, de Waal EC, Uitterlinden AG (1993) Profiling of complex microbial populations by denaturing gradient gel electrophoresis analysis of polymerase chain reactionamplified genes coding for 16S rRNA. Appl Environ Microbiol 59:695-700

Muyzer G, Teske A, Wirsen CO, Jannasch HW (1995) Phylogenetic relationships of Thiomicrospira species and their identification in deep-sea hydrothermal vent samples by denaturing gradient gel electrophoresis of $16 \mathrm{~S}$ rDNA fragments. Arch Microbiol 164:165-172

Paavola M, Olenin S, Leppakoski E (2005) Are invasive species most successful in habitats of low native species richness across European brackish water seas? Estuar Coast Shelf Sci 64:738-750

Pöhler I, Wenderoth DF, Wendt-Potthoff K, Höfle MG (2002) Bacterioplankton community structure and dynamics in enclosures during bio-remediation experiments in an acid mining lake. Water Air Soil Pollut Focus 2:111-121

Ramsing NB, Fossing H, Ferdelman TG, Andersen F, Thamdrup B (1996) Distribution of bacterial populations in a stratified fjord (Mariager Fjord, Denmark) quantified by in situ hybridization and related to chemical gradients in the water column. Appl Environ Microbiol 62:1391-1404

Rheinheimer G, Gocke K, Hoppe HG (1989) Vertical distribution of microbiological and hydrographic-chemical parameters in different areas of the Baltic Sea. Mar Ecol Prog Ser 52:55-70

Schmalenberger A, Schwieger F, Tebbe CC (2001) Effect of primers hybridizing to different evolutionarily conserved regions of the small-subunit rRNA gene in PCR-based microbial community analyses and genetic profiling. Appl Environ Microbiol 67:3557-3563

Schwieger F, Tebbe CC (1998) A new approach to utilize PCRsingle-strand-conformation polymorphism for 16S rRNA gene-based microbial community analysis. Appl Environ Microbiol 64:4870-4876

Simon M, Grossart HP, Schweitzer B, Ploug H (2002) Microbial ecology of organic aggregates in aquatic ecosystems. Aquat Microb Ecol 28:175-211

Skerratt JH, Bowman JP, Hallegraeff G, James S, Nichols PD (2002) Algicidal bacteria associated with blooms of a toxic dinoflagellate in a temperate Australian estuary. Mar Ecol Prog Ser 244:1-15

Stal LJ, Albertano P, Bergman B, von Brockel K, Gallon JR, Hayes PK, Sivonen K, Walsby AE (2003) BASIC: Baltic Sea cyanobacteria. An investigation of the structure and dynamics of water blooms of cyanobacteria in the Baltic Sea - responses to a changing environment. Cont Shelf Res 23:1695-1714

Takai K, Suzuki M, Nakagawa S, Miyazaki M, Suzuki Y, Inagaki F, Horikoshi K (2006) Sulfurimonas paralvinellae sp. nov., a novel mesophilic, hydrogen- and sulfur-oxidizing chemolithoautotroph within the Epsilonproteobacteria isolated from a deep-sea hydrothermal vent polychaete nest, reclassification of Thiomicrospira denitrificans as Sulfurimonas denitrificans comb. nov. and emended description of the genus Sulfurimonas. Int J Syst Evol Microbiol 56:1725-1733 
Teske A, Wawer C, Muyzer G, Ramsing NB (1996) Distribution of sulfate-reducing bacteria in a stratified fjord (Mariager Fjord, Denmark) as evaluated by most-probable-number counts and denaturing gradient gel electrophoresis of PCR-amplified ribosomal DNA fragments. Appl Environ Microbiol 62:1405-1415

Vetriani C, Tran HV, Kerkhof LJ (2003) Fingerprinting microbial assemblages from the oxic/anoxic chemocline of the Black Sea. Appl Environ Microbiol 69:6481-6488

von Wintzingerode F, Göbel UB, Stackebrandt E (1997) Determination of microbial diversity in environmental samples: pitfalls of PCR-based rRNA analysis. FEMS Microbiol Rev 21:213-229

Wasmund N, Pollehne F, Postel L, Siegel H, Zettler ML (2004)

Editorial responsibility: Gerhard Herndl,

Den Burg, Texel, The Netherlands
Biologische Zustandseinschätzung der Ostsee im Jahre 2003. Meereswiss Ber Warnemünde 60:1-87

Webster G, Newberry CJ, Fry JC, Weightman AJ (2003) Assessment of bacterial community structure in the deep sub-seafloor biosphere by $16 \mathrm{~S}$ rDNA-based techniques: a cautionary tale. J Microbiol Methods 55:155-164

Weinbauer MG, Fritz I, Wenderoth DF, Höfle MG (2002) Simultaneous extraction from bacterioplankton of total RNA and DNA suitable for quantitative structure and function analyses. Appl Environ Microbiol 68:1082-1087

Witkowski A, Broszinski A, Bennike O, Anczak-Kostecka B, Jensen JB, Lemke W, Endler R, Kuijpers A (2005) Darss Sill as a border in the fossil record of the Baltic Sea: evidence from diatoms. Q Int 130:97-109

Submitted: July 14, 2006; Accepted: November 4, 2006 Proofs received from author(s): January 16, 2007 